\title{
Preventive interventions for children of parents with depression: international perspectives
}

\author{
Systematic national programs are effectively helping children break the cycle of depression and other \\ mental health problems in families
}

$\mathrm{D}$ epression is a public health problem of major proportions. In Australia, the prevalence rate for depression is over $15 \%$ in adults, and similar rates of illness have been reported around the world. ${ }^{1,2}$ Based on an analysis of a nationally representative data set in the United States, ${ }^{3}$ and assuming the same rates in Australia, there are about 1 million Australian children living with a parent who has experienced depression in the past year.

According to recent reviews, ${ }^{3-5}$ offspring of depressed parents have rates of depression that are between two and four times higher than their counterparts from homes without parental illness. These offspring also have an increased risk for a range of mental health disorders ${ }^{6}$ and associated difficulties, including deficits in academic performance, social relationships, and self-esteem. Because the risks for children of depressed parents have been recognised worldwide, several countries have implemented systematic national programs to assist these families. A recent meta-analysis of prevention trials has shown that prevention of offspring mental health problems is possible. ${ }^{7}$

\section{Risk and resilience}

Both specific (eg, having had a prior depression, having a depressed parent, genetic vulnerabilities) and non-specific (eg, poverty, exposure to violence) risk factors contribute to higher lifetime rates of depression in children of depressed parents. Goodman and Gotlib ${ }^{8}$ have proposed an integrative model to address the cross-generational transmission of risk, and this was the overall organising framework for the US Institute of Medicine ${ }^{3}$ report on depression in parenting. A recent review ${ }^{5}$ highlights key observations of the current research in this area:

- The impact of risk factors is bidirectional. That is, not only do parental behaviours influence child outcome, but children's behaviours influence the parent.

- Both genetic and environmental factors are involved in the transmission of risk, and recent advances in understanding the heritability of depression and gene/ environment influences (eg, whole-genome comparisons, molecular genetics) offer great promise for the future..$^{9-11}$

- Parent-child interactions and parenting style have received significant attention as key factors in the transmission of depression risk from parent to child. ${ }^{12}$ Psychiatric treatment for parents as well as support for parenting can reduce the risk for children. ${ }^{13,14}$

- Although children of depressed parents are at increased risk for depression and other difficulties, many families cope well with these problems. ${ }^{15,16}$ In families with parental depression, Beardslee and Podorefsky ${ }^{17}$ found that
William R Beardslee $\mathrm{BCH}$, AppSci(OT), MHID,
Workforce Development Officer ${ }^{4}$

Tracy R Gladstone Director, Robert $\mathrm{S}$ and Grace W Stone Primary Prevention Initiatives ${ }^{5}$

Nicholas M Kowalenko FRANZCP Clinical Senior Lecturer ${ }^{6}$

1 Baer Prevention Initiatives, Children's Hospital Boston, Boston, MA, United States. 2 Judge Baker Children's Center, Boston, MA, United States.

3 Department of Child and Adolescent Health, National Institute for Health and Welfare, Helsinki, Finland.

4 Children of Parents with a Mental Illness, North Adelaide, SA.

5 Wellesley Centers for Women, Wellesley College, Wellesley, MA, United States.

6 Department of Psychological Medicine, University of Sydney, Sydney, NSW.

William.Beardslee@ childrens.harvard.edu

doi: 10.5694/mjaoll.11289 children who do well have individual, family and community resources that enable them to accomplish ageappropriate developmental tasks, engage in relationships, and understand their surroundings despite the parent's illness. Therefore, important opportunities for resilience promotion in children include supporting families to identify and build upon these resilient processes.

\section{Preventive interventions}

Selected preventive interventions targeted at parents with depression and measuring outcomes in children have a strong evidence base. ${ }^{4}$ A recent meta-analysis by Siegenthaler and colleagues of randomised controlled prevention trials ${ }^{7}$ showed that in studies reviewed, risk to offspring for the same mental disorder from which the parent suffered was reduced by $40 \%$. This applied to internalising but not to externalising symptoms. There are a number of national selective prevention strategies designed specifically for children of parents with depression (see Box 1 online at www.mja.com.au/ mjaopen). These have in common a focus on strengthening parenting and addressing youth needs. We discuss two national programs in detail below.

\section{Finland}

The Effective Child and Family Programme (ECFP) $)^{18,19}$ was launched in Finland in 2001 and is supported by the Ministry of Social Affairs and Health. The aim of the program is to make a system change in health and social services so that professionals can attend to the needs of adult patients and their children. The work began in families with psychiatric problems but expanded quickly to substance use issues and physical health problems in parents, and more recently, to issues of poverty and criminality in families. The ECFP is also involved in building community-based multiprofessional services for all families with multiple needs. Under Finnish health and child welfare law, services for adult patients must also attend to the needs of their children. This applies to mental and physical health and substance use services, social services including income-benefit services, and the criminal justice system. As many parents with mental or other illnesses have not sought treatment, the program is also active with children in kindergartens and schools.

Based on several smaller audits, it seems fair to say that it is mainstream practice now in most Finnish psychiatric services to discuss children and parenting with the patient. Some of the success factors for the ECFP include (i) the program is situated in an organisation that has national responsibility; (ii) work started at multiple levels 
simultaneously (national and community levels, decisionmakers and grassroot practitioners, families, mass media); (iii) the initial training was extensive and provided expert practitioners and trainers across the country; (iv) a family of methods was developed to be used in different services and by those with different professional orientations; (v) the methods include a low-threshold option (Let's Talk About Children), which does not depart in format from traditional patient-clinician sessions; and (vi) research on the two core methods was carried out producing an evidence base for the work. ${ }^{20}$ A remaining challenge is to ensure that the work remains of high quality when the program has expanded to become nationwide with thousands of practitioners and families participating.

\section{Australia}

Recently, the Children of Parents with a Mental Illness (COPMI) national initiative has developed resources to improve support for families where a parent has depression. The Family Focus intervention - based on the Family Talk Intervention developed in the US by Beardslee and colleagues ${ }^{21}$ (see Box 2 online at www.mja.com.au/ mjaopen) - includes a DVD for families and an online workforce education resource that provides training for mental health professionals.

Primary care settings have been identified as potential facilitators of the Family Focus DVD and intervention, due to the availability of existing services and pathways for the treatment of depression. Similarly, the current focus on the provision of time-limited, evidence-based interventions in general practice, and the collaborative networks established as part of primary mental health and national health reforms, highlight the significant role of primary care in promoting the mental health of children of parents with depression. ${ }^{22,23}$

Before the implementation of the Family Focus DVD and intervention in primary care, there are a number of changes needed that would enable mental health professionals to facilitate these interventions. These include increased support for primary prevention, an expansion of individual-orientated interventions to become family focused, and the establishment of pathways by which families can access the intervention (unpublished data, COPMI). Strategies to promote access to the DVD and intervention in primary care settings are being investigated as part of a pilot test in 2012. This work extends previously developed resources that aim to promote sustainability of COPMI initiatives. ${ }^{24}$

\section{Families and depression in primary care}

Most parents who are seeking help for depression will present to primary care physicians. Key factors for physicians are (i) recognising depression; (ii) helping parents obtain treatment; (iii) understanding children's concerns and developmental needs; (iv) offering psychoeducation; (v) providing parental guidance; and (vi) follow-up.

It is important for a primary care practitioner to ask parents if they have experienced depressive symptoms, particularly if they are in high-risk groups such as having had prior depression, recent losses or multiple risk factors (poverty and social isolation). In a number of countries, screening has been recommended for new parents, and parents in whom depression is suspected. Where screening tools are readily available and are paired with access to treatment, they can assist the practitioner. Evidence-based treatment for depression should be instituted. Assisting patients who are parents to obtain treatment when needed is essential.

Eliciting parent concerns is also important. Many parents are worried about possible long-term effects of depression on their children. Research demonstrates that depression in parents affects children differently, depending on the child's developmental stage. ${ }^{3}$ Early in life, attachment between parent and child may be disrupted, and symptoms such as difficulties in establishing routines for the child, frequent doctor visits, and difficulties with feeding and sleeping may signal parental depression. In the preschool and school years, difficulties accomplishing developmental milestones may signal the presence of depression, and anxiety symptoms before puberty and depressive symptoms after puberty are very common in children of depressed parents. During adolescence, the rates of diagnosis of depression and anxiety in children of depressed parents increase markedly, and these should be identified and attended to as well.

Depression is not well understood either in society in general or by parents. Helping families to identify their own strengths and to focus on them, providing clear psychoeducation on what parents can do to support the children and helping them to access and use out-of-home resources has proved valuable in a wide array of settings. Depending on the local circumstances, parents might be able to turn to extended family, friends, non-government organisations and family services. They can learn to preserve essential parenting functions despite their illness (eg, supporting their child's friendships and activities). In fact, children themselves place more emphasis on the importance of peer relationships as a form of support than do parents or mental health professionals. ${ }^{25,26}$ It is also important to emphasise that while there is increased risk, many children do well, and no child is irrevocably damaged.

Primary care mental health professionals are in an excellent position to provide long-term follow-up and ask periodically about the children of depressed parents. The Beardslee $^{21}$ and Compas ${ }^{27,28}$ projects provided long-term follow-up, and the benefits of these interventions were revealed over time. We believe that follow-up with families with depressed parents is essential and can greatly strengthen the initial interventions. A list of resources for practitioners is provided in the box.

\section{Conclusion}

Systematic approaches, such as those used in Finland and Australia, offer the best opportunity for large-scale impact, and there are important strategies that practitioners can employ directly with families.

Although many of us began this work in an expert role, we came to recognise that in working with families with parental depression, there are two types of experts: the parents and children who are experts on their own 


\section{Parental depression resources}

\section{Recommended readings}

Beardslee WR. When a parent is depressed: how to protect your children from the effects of depression in the family. Boston, New York, London: Little, Brown and Company, 2002

Goodman SH, Gotlib IH. Children of depressed parents: mechanisms of risk and implications for treatment. Washington, DC: American Psychological Association, 2002 National Research Council. Depression in parents, parenting, and children: opportunities to improve identification, treatment, and prevention. Washington, DC: The National Academies Press, 2009

Solantaus T. Let's talk about children [a manual for a twosession discussion with parents who suffer from mental health problems]. Available at http://www.thl.fi (expected release in English in late 2012)

Beardslee WR, Gladstone TR, Wright EJ, Cooper AB. A family-based approach to the prevention of depressive symptoms in children at risk: evidence of parental and child change. Pediatrics 2003; 112: el19-131

\section{Training resources}

Family Focus (Australia). Online training in the Family Focus intervention based on the US Family Talk intervention. http://www.copmi.net.au (expected release in late 2012) Families Preventing and Overcoming Depression (USA). Family Talk intervention [online course]. http://www.fampod.org (accessed Mar 2012)

\section{Resources for families}

Family Focus: talking together about parental depression and anxiety [DVD]. http://www.copmi.net.au (expected release in late 2012)

Nicholson J, Clayfield JC, Phillips SM. Parenting well when you're depressed: a complete resource for maintaining a healthy family. Oakland, CA: New Harbinger Publications, 2001

A list of resources for health professionals and families where a parent has depression is available at http://www.copmi.net.au

families, and the practitioner with expertise in the treatment of depression and the management of preventive interventions. In this sense, we came to develop partnerships with families and learned a great deal from them.

Competing interests: No relevant disclosures.

Provenance: Commissioned; externally peer reviewed

1 Australian Bureau of Statistics. National survey of mental health and wellbeing: summary of results 2007. Canberra: ABS, 2008. (ABS Cat. No. 4326.0.) http://www.abs.gov.au/AUSSTATS/abs@.nsf/DetailsPage/ 4326.02007? OpenDocument (accessed Mar 2012).

2 Lopez AD, Mathers CD, Ezzati M, et al, editors. Global burden of disease and risk factors. Washington, DC: World Bank and Oxford University Press, 2006. http://www.dcp2.org/pubs/GBD (accessed Mar 2012).

3 National Research Council. Depression in parents, parenting, and children: opportunities to improve identification, treatment, and prevention. Washington, DC: The National Academies Press, 2009. http://www.nap.edu/catalog.php?record_id=12565 (accessed Mar 2012).

4 National Research Council. Preventing mental, emotional, and behavioral disorders among young people: progress and possibilities. Washington, DC: The National Academies Press, 2009. http:// www.nap.edu/catalog.php?record_id=12480 (accessed Mar 2012).
5 Beardslee W, Gladstone TRG, O'Connor EE. Transmission and prevention of mood disorders among children of affectively ill parents: a review. J Am Acad Child Adolesc Psychiatry 2011; 50: 1098-1109.

6 Dean K, Stevens H, Mortensen PB, et al. Full spectrum of psychiatric outcomes among offspring with parental history of mental disorder. Arch Gen Psychiatry 2010; 67: 822-829.

7 Siegenthaler $E$, Munder T, Egger M. Effect of preventive interventions in mentally ill parents on the mental health of the offspring: systematic review and meta-analysis. J Am Acad Child Adolesc Psychiatry 2012; 51 : 8-17.

8 Goodman SH, Gotlib IH. Transmission of risk to children of depressed parents: integration and conclusions. In: Goodman SH, Gotlib IH, editors. Children of depressed parents: mechanisms of risk and implications for treatment. Washington, DC: American Psychological Association, 2002: 307-326

9 Kendler KS, Baker JH. Genetic influences on measures of the environment: a systematic review. Psychol Med 2007; 37: 615-626.

10 Hochberg Z, Feil R, Constancia M, et al. Child health, developmental plasticity, and epigenetic programming. Endocr Rev 2011; 32: 159-224.

11 Bagot RC, Meaney MJ. Epigenetics and the biological basis of gene $x$ environment interactions. J Am Acad Child Adolesc Psychiatry 2010; 49: 752-771.

12 Rutter M. Commentary: Some focus and process considerations regarding effects of parental depression on children. Dev Psychol 1990; 26: 60-67.

13 Weissman MM, Pilowsky DJ, Wickramaratne PJ, et al. Remissions in maternal depression and child psychopathology: a STAR*D-child report. JAMA 2006; 295: 1389-1398.

14 Swartz HA, Frank E, Zuckoff A, et al. Brief interpersonal psychotherapy for depressed mothers whose children are receiving psychiatric treatment. Am J Psychiatry 2008; 165: 1155-1162.

15 Beardslee WR. Out of the darkened room: when a parent is depressed; protecting the children and strengthening the family. Ist ed. Boston: Little, Brown and Company, 2002.

16 Hammen C. Depression runs in families: the social context of risk and resilience in children of depressed mothers. New York, NY: SpringerVerlag, 1991.

17 Beardslee WR, Podorefsky D. Resilient adolescents whose parents have serious affective and other psychiatric disorders: importance of self-understanding and relationships. Am J Psychiatry 1988; 145: 63-69.

18 Solantaus T, Toikka S. The Effective Family Programme: preventative services for the children of mentally ill parents in Finland. Int J Ment Health Prom 2006; 8: 37-44.

19 Toikka S, Solantaus T. The Effective Family Programme II: cinicians' experiences of training in promotive and preventative child mental health methods. Int J Ment Health Prom 2006; 8: 4-10.

20 Solantaus T. Puras D. Caring for children of parents with mental health problems - a venture into the historical and cultural processes in Europe. Int J Ment Health Prom 2010; 12: 27-36.

21 Beardslee WR, Wright EJ, Gladstone TR, Forbes P. Long-term effects from a randomized trial of two public health preventive interventions for parental depression. J Fam Psychol 2009; 21: 703-713.

22 Pirkis J, Harris M, Hall W, Ftanou M. Evaluation of the better access to psychiatrists, psychologists and general practitioners through the Medicare Benefits Schedule initiative. Summative evaluation. Final report. Melbourne: Centre for Health Policy, Programs and Economics,The University of Melbourne, 2011. http://www.health. gov.au/internet/main/publishing.nsf/content/E31B4C0752BAE99FCA 25784C0078BFCD/\$File/sum.pdf (accessed Mar 2012).

23 Parslow RA, Lewis V, Marsh G. The general practitioner's role in providing mental health services to Australians, 1997 and 2007: findings from the national surveys of mental health and wellbeing. Med J Aust 2011; 195: 205-209.

24 Owen, S. Organisational systems and services for children of parents with mental illness and their families: processes of change and sustainability. Adm Policy Ment Health 2010; 37: 399-407.

25 Maybery D, Ling L, Szakacs E, Reupert A. Children of a parent with a mental illness: perspectives on need [internet]. Adv Ment Health 2005; 4: 78-88.

26 Gladstone BM, Boydell KM, Seeman MV, McKeever PD. Children's experiences of parental mental illness: a literature review. Early Interv Psychiatry 2011; 5: 271-289. doi: 10.1111/j.1751-7893.2011.00287.x.

27 Compas BE, Forehand R. Keller $\mathrm{G}$, et al Randomized controlled trial of a family cognitive-behavioral preventive intervention for children of depressed parents. J Consult Clin Psychol 2009; 77: 1007-1020.

28 Compas BE, Forehand R, Thigpen JC, et al. Family group cognitivebehavioral preventive intervention for families of depressed parents: 18- and 24-month outcomes. J Consult Clin Psychol 2011; 79: 488-499. 


\section{National preventive strategies for children of parents with depression}

\section{Strategy}

Australia

Children of Parents with a Mental Illness (http://www.copmi.net.au)

\section{Description}

Targets children 0 -18 years of age, promoting better mental health outcomes in children of parents with a mental illness

Disseminates good practice and provides workforce training resources

Provides information for family members with a mental illness

Aims to embed support for families into health, social service, education, and community sectors through strategic collaboration*

Highlighted as an action in priority 2 of the Fourth National Mental Health Plan ${ }^{\dagger}$

Finland

Effective Child and Family Programme

(http://info.stakes.fi/toimivaperhe/EN/index.htm)

Provides health and social services with evidence-based methods to promote family life children's wellbeing and development, and to prevent child problems

Established in response to the Finnish mandate that health and social services attend to both patients and their children

Aims to build a functional multisectoral service system in community based services Includes family-intervention sessions $21,24,25$ and family support groups, combining peer support and family processes

\section{Netherlands}

Preventive program for children of mentally ill and substance-misusing parents (http://www.trimbos.org)

Developed by the Trimbos Institute, Netherlands Institute of Mental Health and Addiction

Includes a parent-baby intervention ${ }^{\ddagger}$

Includes family-intervention sessions $21,24,25$

\section{Norway}

Adults for Children (Voksne for Barn) (http://www.vfb.no) Long-standing organisation focused on the wellbeing of children and adolescents, especially related to mental health

Offers promotion programs, parent guidance and training of professionals

Offers training for the Family Talk Intervention

\section{Sweden}

Children as Relatives (Barn som Anhöriga)

(http://www.barnsomanhoriga.se)

Provides information to professionals about children of parents with a mental illness

Includes family intervention sessions $21,24,25$

Supported by the Swedish National Board of Health and Welfare

\section{United States}

No coordinated national effort, but many good programs

International collaborations

Nordic Forum — Focus on Children

Represents continuous collaboration and annual conferences among the Nordic countries

Paved the way for proactive legislation rather than reactive legislation

Contributed to legislation in Sweden and Norway mandating that health services attend to both parents and children

Child and adolescent mental health in enlarged European Focuses on the intergenerational transfer of mental illness and substance use Union: development of effective policies and practices (http://www.camhee.eu)

International conferences

Includes a work package for families with parental mental illness

Inaugural World Children of Parents with a Mental Illness Conference, Adelaide, Australia, 2009

Voksne for Barn, Developing Strength and Resilience in Children, Oslo, Norway, 2010

Third International World Congress on Children of Parents with Mental Illness, Vancouver, Canada, 2012

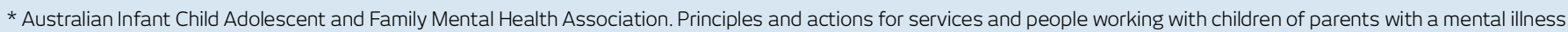

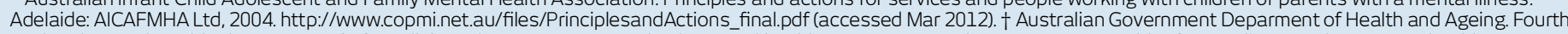

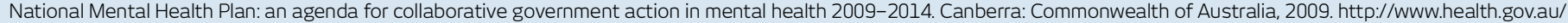
internet/main/publishing.nsf/content/mental-pubs-f-plan09 (accessed Mar 2012). ‡ van Doesum KT, Riksen-Walraven JM, Hosman CMH, Hoefnagels C.

A randomized controlled trial of a home-visiting intervention aimed at preventing relationship problems in depressed mothers and their infants. Child Dev $2008 ; 79: 547-561$. 


\begin{tabular}{|c|c|c|c|c|}
\hline Intervention & $\begin{array}{l}\text { Development and } \\
\text { implementation }\end{array}$ & Target group & Description & Outcomes \\
\hline Family Talk & $\begin{array}{l}\text { Developed in the United } \\
\text { States by Beardslee et al, }{ }^{21} \\
\text { and implemented in the US, } \\
\text { Finland, Holland, Sweden, } \\
\text { Norway and Costa Rica }\end{array}$ & $\begin{array}{l}\text { Families where a } \\
\text { parent has depression }\end{array}$ & $\begin{array}{l}\text { Two public health interventions } \\
\text { - Family Talk (6-1l sessions) } \\
\text { and a two-session public health } \\
\text { lecture - focusing on providing } \\
\text { education to parents. Links } \\
\text { educational material to the unique } \\
\text { experiences of families and helps } \\
\text { families develop a plan for dealing } \\
\text { with depression and building } \\
\text { resilience in family members }\end{array}$ & $\begin{array}{l}\text { A long-term randomised trial showed } \\
\text { strong, sustained effects for both } \\
\text { strategies, with a greater benefit for } \\
\text { Family Talk. Outcomes included } \\
\text { diminished adolescent internalising } \\
\text { symptoms, increased positive family } \\
\text { interactions, and increased rates of } \\
\text { recognition and treatment for children } \\
\text { who did eventually experience } \\
\text { depression }\end{array}$ \\
\hline $\begin{array}{l}\text { Family group } \\
\text { cognitive } \\
\text { behavioural } \\
\text { intervention }\end{array}$ & $\begin{array}{l}\text { Developed and implemented } \\
\text { in the US by Compas } \\
\text { et } \mathrm{al}^{27,28}\end{array}$ & $\begin{array}{l}\text { Family groups where } \\
\text { a parent has } \\
\text { experienced } \\
\text { depression }\end{array}$ & $\begin{array}{l}\text { 10-session family group model } \\
\text { in which families are enrolled } \\
\text { in groups of four and are seen } \\
\text { in parent or family groups. } \\
\text { Participants are taught to } \\
\text { understand and cope with } \\
\text { depression }\end{array}$ & $\begin{array}{l}\text { At the } 24 \text {-month follow-up, relative } \\
\text { to the control conditions, significant } \\
\text { parent and child benefits occurred, } \\
\text { including significantly fewer } \\
\text { depressive episodes in children }\end{array}$ \\
\hline $\begin{array}{l}\text { Family cognitive } \\
\text { behavioural } \\
\text { preventive } \\
\text { intervention }\end{array}$ & $\begin{array}{l}\text { Developed and implemented } \\
\text { in the US by Garber et al* }\end{array}$ & $\begin{array}{l}\text { Adolescent groups } \\
\text { that have a parent } \\
\text { with depression }\end{array}$ & $\begin{array}{l}\text { 8-session group cognitive } \\
\text { behavioural preventive intervention } \\
\text { for adolescents with a depressed } \\
\text { parent and with symptoms of } \\
\text { depression and/or a past } \\
\text { depression history }\end{array}$ & $\begin{array}{l}\text { Relative to adolescents in the control } \\
\text { group, adolescents who participated } \\
\text { in the program evidenced fewer } \\
\text { depressive episodes over an 8-month } \\
\text { follow-up, and benefits were } \\
\text { moderated by the presence of current } \\
\text { parental depression. Longer follow-up } \\
\text { of this sample is currently underway }\end{array}$ \\
\hline $\begin{array}{l}\text { Let's Talk About } \\
\text { Children }\end{array}$ & $\begin{array}{l}\text { Developed and implemented } \\
\text { in Finland by Solantaus }{ }^{\dagger}\end{array}$ & $\begin{array}{l}\text { Parents/families } \\
\text { where a parent has } \\
\text { depression. Also } \\
\text { designed for other } \\
\text { psychiatric problems }\end{array}$ & $\begin{array}{l}\text { A manual-based, two-session } \\
\text { intervention with parents }\end{array}$ & $\begin{array}{l}\text { A randomised trial with 18-month } \\
\text { follow-up comparing Family Talk and } \\
\text { Let's Talk About Children. Both } \\
\text { interventions were found to be safe } \\
\text { and feasible. In both interventions, } \\
\text { there were significant decreases in } \\
\text { children's emotional symptoms and } \\
\text { anxiety, and increases in prosocial } \\
\text { behaviour. Family Talk was found } \\
\text { to be more effective in reducing } \\
\text { emotional symptoms }\end{array}$ \\
\hline
\end{tabular}

* Garber J, Clarke GN, Weersing VR, et al. Prevention of depression in at-risk adolescents: a randomized controlled trial. JAMA 2009; 301: 2215-2224. † Solantaus T, Toikka S, Alasuutari M, et al. Safety, feasibility and family experiences of preventive interventions for children and families with parental depression. Int J Ment Health Prom $2009 ; 11$ : 15-24. Solantaus T, Paavonen EJ, Toikka S, Punamäki RL. Preventive interventions in families with parental depression: children's psychosocial symptoms and prosocial behaviour. Eur Child Adolesc Psychiatry 2010; 19: 883-892. 